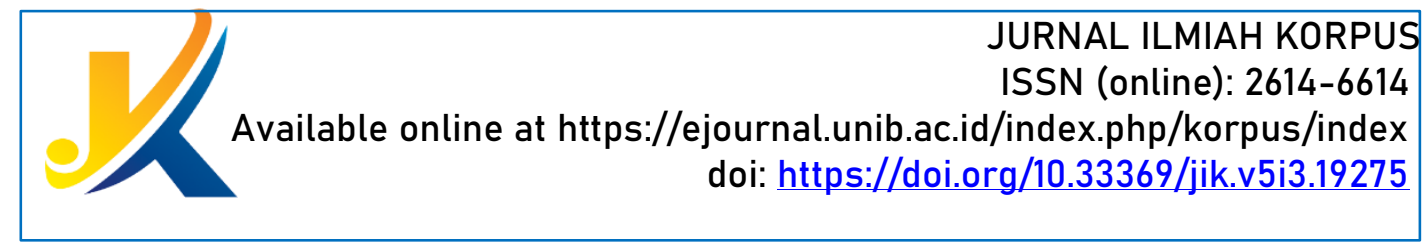

\title{
MORAL DALAM NOVEL 212 CINTA MENGGERAKKAN SEGALANYA KARYA HELVY TIANA ROSA DAN BENNY ARNAS
}

\author{
${ }^{1}$ Velly Roista; ${ }^{2}$ Emi Agustina; ${ }^{3}$ Amril Canrhas \\ Program Studi Pendidikan Bahasa Indonesia \\ Universitas Bengkulu \\ Korespondensi: Vellyroista879@gmail.com
}

Abstrak

Penelitian ini bertujuan untuk mengungkapkan dan menguraikan mengapa peristiwa 212 itu terjadi dan nilai moral yang terdapat pada novel tersebut. Metode yang digunakan dalam penelitian ini adalah metode deskriptif analisis. Teknik pengumpulan data dalam penelitian ini adalah studi pustaka, langkah-langkah pengumpulan data adalah (1) membaca novel 212 Cinta Menggerakkan Segalanya karya Helvy Tiana Rosa dan Benny Arnas secara keseluruhan untuk memperoleh gambaran secara umum tentang karya, (2) membaca ulang novel sambil menandai bagian karya yang berhubungan nilai-nilai moral, (3) mengumpulkan seluruh nilai-nilai moral yang sudah ditandai ke dalam daftar pengumpulan data. Teknik analisis data yang digunakan dalam penelitian ini adalah model analisis konten (Content Analysis). Analisis konten merupakan strategi untuk menangkap pesan dalam sebuah karya sastra. Berdasarkan hasil penelitian di atas, disimpulkan bahwa novel 212 Cinta Menggerakkan Segalanya mengekspresikan tentang rasa cinta kepada agama Islam. Rasa cinta itulah yang mengerakkan jutaan hati manusia melakukan segalanya. Dan juga nilai-nilai moral yang terdapat dalam novel ditemukan nilai moral baik dan buruk. Nilai moral baik yang dominan dalam novel 212 Cinta Menggerakkan Segalanya yakni wujud keimanan, karena keimanan itulah yang membuat mereka bergerak, meliputi: mencintai Al-Qur'an, konsisten terhadap agama, penolong, pantang menyerah, kehendak, dan kebahagiaan. Moral buruk yang dimiliki tokoh Rahmat dan pasukan polisi terdiri atas berbohong, berbuat jahat, perbuatan yang tidak menyenangkan seperti, menghalangi orang bebuat kebaikan, dan sikap tidak peduli kepada orang lain. Berdasarkan hasil penelitian dapat dikategorikan novel dengan nilai moral baik, karena menggambarkan pembelajaran moral yang baik bagi pembacanya.

Kata Kunci: Nilai Moral, Novel 212 Cinta Menggerakkan Segalanya

\section{Abstract}

This study aims to reveal and describe why the events occurred and the moral values contained in the novel.The study employed a descriptive analysis method. Data were collected through carrying out literature studies, and the steps of them were (1) reading the 212 Novel Cinta Menggerakkan Segalanya Written by Helvy Tiana Rosa and Benny Arnas as a whole to get a general picture of the work; (2) rereading the novel while marking the part of the work the deals with moral;and (3) collecting all the moral that have been marked into the list of data collection. Further, to analyze the data, researcher applied the following step, namely The data analysis technique used in this study is a content analysis model. Content analysis is a strategy to capture messages in a literary work. Based on the results of the research above, it is concluded that the novel 
Velly Roista; Emi Agustina; Amril Canrhas

millions of human hearts to do everything. And also there are moral values contained in the novel found good and bad moral values. Good moral values consist of faith, which includes loving the Qur'an, being consistent with religion, being grateful, trusting, praying, dhikir and covering aurat. And bad morals consist of lying, doing evil, doing unpleasant things. Results Based on the research, it can be categorized as a novel with good moral values, because it describes good moral learning for its readers.

Keywords: The form of moral values, 212 Novel Cinta Menggerakkan Segalanya.

\section{PENDAHULUAN}

Manusia membutuhkan cerita tentang berbagai masalah hidup untuk memenuhi kebutuhan batinnya, memperkaya pengalaman jiwanya, dalam hal ini pengarang mempunyai sifat peka, reaktif, dan menghayati kehidupan ini secara lebih intensif, sehingga menyadari kebutuhan tersebut. Oleh karena itu, pengarang memberi makna kehidupan mengajak pembaca untuk merenungkan kehidupan melalui pernyataan yang sengaja diciptakan dan dikreasikannya (Nurgiyantoro, 2013:104). Novel merupakan salah satu karya fiksi yang mengungkapkan aspek-aspek kemanusiaan yang lebih mendalam dan disajikan dengan halus. Novel selalu memberikan hal yang baru bagi pembaca, baik tentang kehidupan sosial maupun budaya. Novel memiliki unsur pembangun yaitu, unsur intrinsik atau unsur yang membangun karya sastra itu sendiri dan unsur ekstrinsik atau unsur yang membangun karya sastra dari luar. Adapun unsur yang membangun karya sastra dari dalam atau intrinsik yaitu, tema, amanat, alur, penokohan, latar, sudut pandang, gaya bahasa sedangkan unsur ekstrinsik hubungsn karya sastra dengan dunia di luar karya sastra itu sendiri (Chanafiah, Yayah dan Emi Agustina, 2014:3)

Menurut Nurgiyantoro (2013:429) secara umum moral menyarankan pada pengertian ajaran tentang baik dan buruk yang diterima mengenai perbuatan, sikap ,kewajiban, akhlak, budi pekerti, dan susila. Moral dalam karya sastra biasanya mencerminkan pandangan hidup pengarang yang bersangkutan pandangan tentang nilai-nilai kebenaran, dan hal itulah yang ingin disampaikan kepada pembaca. Moral dalam cerita biasanya dimaksudkan sebagai suatu sarana yang berhubungan dengan ajaran moral tertentu yang bersifat praktis yang dapat diambil lewat cerita yang bersangkutan oleh pembaca. Moral adalah baik buruk perbuatan dan kelakuan atau suatu istilah yang digunakan untuk menentukan batas-batas dari sifat, perangai, kehendak atau perbuatan secara layak dapat dikatakan benar, salah, baik, buruk (Asmaran, 2002:8).

Novel yang dijadikan objek material adalah novel 212 Cinta Menggerakkan Segala Karya Helvy Tiana Rosa dan Benny Arnas. Novel tersebut merupakan salah satu karya sastra yang memuat nilai-nilai moral. Novel ini diangkat dari peristiwa aksi damai membela Islam yakni Cinta Menggerakkan Segalanya yang dihasilkan dari sebuah peristiwa yang berbau agama dan politik di Indonesia yaitu penistaan terhadap agama yang dilakukan oleh Gubernur Basuki Tjahaja Purnama (Ahok) pada tanggal 2 Desember 2016 di daerah DKI Jakarta sebab pidatonya yang menyinggung surat Al-Maidah ayat 51. Sesuai dengan judulnya, novel ini berbicara tentang kekuatan cinta tuhan yang mampu 
menggerakkan hati nurani manusia melaksanakan aksi 212 dan juga membawa pesan damai dari umat Islam Indonesia. Kompleksitas karakter tokoh dihidupkan pengarang masing-masing memiliki kepribadian yang kentara berseberangan, namun terpaksa harus berinteraksi. Dari semua tokoh yang ada Abah Zainal dan Rahmat adalah tokoh paling menjengkelkan dalam arti sebenarnya. Keduanya kepala batu membuat pembaca gregetan. Tetapi, cinta tuhan yang mampu menyatukan hubungan antara anak dan orang tua, karena mereka memiliki ikatan emosional yang kuat, contohnya ketika Kiai Zainal sakit, anaknya sangat mencemaskan ayahnya. Serta sanggup menyatukan perbedaan dan menggerakkan manusia yang berbeda keyakinan untuk melakukan kebaikan yang sulit dipahami bagi mereka yang jiwanya telah mati. Cinta Tuhandihadirkan lagi di hati orang-orang yang sempat berpaling jauh dari-Nya dengan cara Tuhan yang mampu membolak-balikkan hati manusia, sehingga mampu menggerakkan jutaan hati manusia. Oleh sebab itu, penulis menguraikan struktur novel, sebab akibat peristiwa itu, serta nilai moral yang terdapat dalam novel 212 Cinta Menggerakkan Segalanya Karya Helvy Tiana Rosa dan Benny Arnas. Novel tidak lepas dari sistem sosial budaya yang melengkapinya. Dengan demikian, suatu fenomena sosial dapat menjadi salah satu unsur sebuah novel. Setiap novel sebagai ciptasastra pada umumnya mempunyai kandungan nilai- nilai moral. Artinya, pengarang berusaha aktifkan pembaca untuk menerima gagasan-gagasan tentang berbagai segi kehidupan(Nurgiyantoro, 2013:330). Begitupula dalam novel 212 Cinta Menggerakkan Segalanya karya Helvy Tiana Rosa dan Benny Arnas telah berhasil mendeskripsikan sebuah gambar nilai moral. Berdasarkan hasil pembacaan awal penelitian nilai moral yang terdapat dalam novel 212 Cinta Menggerakan Segalanya Karya Helvy Tiana Rosa dan Benny Arnas hal ini ditegaskan pada kutipan:

"Ini bukan tentang saya. Bukan hanya tentang saya, kamu, atau diri kita sendiri. Ini tentang rasa cinta pada agama ini'(Rosa dan Arnas, 2018: 119).

"Kamu ingat, Berapa orang yang tadi berangkat? Dan bagaimana saatini? "Kamu bisa menghitung mereka? Tak kurang dari 10.000 orang! Kami adalah mata rantai-mata rantai yang berkaitan itu, yangmembentuk kekuatan tanpa kami rencanakan. Kamu masih mau bertanya bagaimana ini terjadi? ini karena cinta. cinta apa? cinta pada agama ini!" (Rossa dan Arnas, 2018:121).

Kutipan di atas, menggambarkan rasa cinta pada agama yang membuat orang tergerak melakukan segalanya dalam membela agama Islam. Hal itu ditegaskan dari kutipan di atas yang merupakan wujud nilai moral dari tokoh Kiai Zainal dan umat muslim yang memiliki sikap tangguh kepada agama yang dianutnya, siapapun yang melecehkan agamanya akan dilawan walaupun orang itu adalah sahabatnya. Kutipan kedua merupakan wujud penerapan kecintaan terhadap agama Islam karena agama Islam dinistakan, sehingga muncul kemantapan hati Kiai Zainal dan umat muslim di Indonesia untuk melakukan aksi dalam membela agama Islam. Berdasarkan hal tersebut hal itu muncul 
karena terdapat nilai-nilai moral yang ada dalam diri mereka untuk melakukan aksi tersebut. Mengingat bahwa agama itu pada dasarnya bukan untuk disepelehkan atau dilecehkan, tapi amat penting untuk diperjuangkan

Pemilihan nilai moral menurut penulis sangat relevan dengan keadaan sekarang karena banyak fenomena yang terjadi di tengah masyarakat yang tidak mengindahkan tentang perilaku-perilaku menyimpang, misalnya peristiwa yang memiliki nilai-nilai dari sudut pandang agama. bagaimana seseorang yang beragama artinya yang mempercayai satu agama itu, merasa agama yang diyakininya itu dihina atau dilecehkan karena hal tersebut timbullah semangat juang seseorang melakukan berbagai hal membela agama. Perlu kita cermati siapa pun di dunia ini tidak boleh haknya ajaran agama itu saling menjatuhkan dan saling menjelekkan antara satu dengan yang lain atau keyakinan satu dengan keyakinan yang lainnya. Kernyataan sekarang masih banyak penurunan moral pada generasi muda, disebabkan kurangnya pemahaman nilai-nilai moral yang tertanam pada diri mereka. Penelitian ini diharapkan dapat menguraikan tentang penyebab inti dari permasalahan, serta wujud nilai-nilai moral yang terkandung dalam novel tersebut sehingga, dapat menambah wawasan yang relevan. Penulis berharap dengan dilakukannya penelitian ini dapat memberikan suatu pencerahan kepada pembaca agar selalu menanamkan dan mengamalkan nilainilai moral. Nilai moral maerupakan sifat dan hal yang paling penting dan berguna bagi manusia untuk proses perubahan sikap, dan tingkah laku seorang manusia. Maka, nilai-nilai moral sangat penting dan diharapkan berperan besar terhadap kemajuan kepribadian tingkah laku seseorang.

Sehubungan hal di atas, penulis tertarik untuk mengkaji nilai-nilai moral dalam novel 212 Cinta Menggerakkan Segalanya karya Helvy Tiana Rosa dan Benny Arnas untuk menguraikan struktur novel, sebab akibat dari peristiwa itu, serta wujud nilai moral yang terdapat dalam novel tersebut, tidak hanya secara eksplisit melainkan secara tepat dan rinci. Jadi, untuk menguraikan sebab akibat, serta wujud nilai-nilai moral dilakukan perenungan dan interpretasi, sehingga dapat membantu dan bermanfaat bagi pembaca untuk memahami nilai-nilai moral yang ada pada novel tersebut. Berdasarkan latar belakang di atas, penulis akan melakukan penelitian ini dengan judul "Moral dalam Novel 212 Cinta Menggerakkan Segalanya karya Helvy Tiana Rosa dan Benny Arnas.

\section{METODE}

Penelitian ini menggunakan metode deskriptif analisis. Metode deskriptif adalah suatu bentuk yang paling dasar. Menurut Moleong (2014:11) metode deskriptif adalah data yang terurai dalam bentuk kata-kata, gambarangambaran, dan bukan dalam bentuk angka-angka. Metode deskriptif analisis dengan cara mendeskripsikan fakta-fakta yang kemudian disusul dengan analisis (Ratna, 2012:53). Demikian, Metode deskriptif analisis digunakan untuk menggambarkan fakta-fakta yang berhubungan dengan nilai moral dalam novel 212 Cinta Menggerakkan Segalanya Karya Helvy Tiana Rosa dan Benny Arnas.

Pendekatan yang digunakan dalam penelitian ini adalah pendekatan struktural. Pendekatan ini merupakan suatu pendekatan yang penting, sebab pendekatan apapun yang dilakukan pada dasarnya bertumpu atas karya sastra itu 
sendiri. Pendekatan struktural memusatkan perhatian semata-semata pada unsur-unsur, yang di kenal dengan analisis intrinsik. Penelitian ini menggunakan dasar pemikiran struktural yang memandang analisis struktur sebagai salah satu cara mencari kenyataan dari kaitan-kaitan antara unsur yang membangunnya. Setelah data-data mengenai unsur-unsur intrinsik dan nilai moral yang terdapat dalam setiap peristiwa yang dikumpulkan, penulis kemudian mengelompokkan jenis data tersebut. Kemudian menginterpretasikannya sesuai dengan kemampuan penulis agar hasil itu mudah dipahami.

Data dalam penelitian ini adalah kutipan berupa kata, frasa, klausa, dan kalimat yang mengandung nilai moral dalam novel 212 Cinta Menggerakkan Segalanya Karya Helvy Tiana Rosa dan Benny Arnas. Dan sumber data dalam penelitian ini ialah novel 212 Cinta Menggerakkan Segalanya Karya Helvy Tiana Rosa dan Benny Arnas, yang ditampilkan pada tahun 2018 oleh Republika, covernovel berwarna putih dengan kombinasi gambar Monas dan beberapa orang dengan latar ribuan orang, cetakan pertama ukuran buku 13,5 x 20,5 cm dengan 262 halaman.

Penelitian ini menggunakan studi pustaka, yang secara khusus meneliti teks yakni novel 212 Cinta Menggerakkan Segalanya Karya Helvy Tiana Rosa dan Benny Arnas dengan memanfaatkan teknik daftar data. Adapun langkahlangkahnya dalam penelitian yang dilakukan dalam pengumpulan data: 1) membaca novel 212 Cinta Menggerakkan Segalanya Karya Helvy Tiana Rosa dan Benny Arnas secara keseluruhan, 2) membaca ulang novel 212 Cinta Menggerakkan Segalanya Karya Helvy Tiana Rosa dan Benny Arnas sambil menandai bagian karya yang berhubungan dengan masalah penelitian, 3) mengumpulkan seluruh data nilai-nilai moral yang sudah ditandai pada teks novel 212 Cinta Menggerakkan Segalanya Karya Helvy Tiana Rosa dan Benny Arnas ke dalam daftar pengumpulan data. Teknik analisis data yang digunakan dalam penelitian ini adalah model analisis konten (Content Analysis). Analisis konten merupakan strategi untuk menangkap pesan dalam sebuah karya sastra. Tujuan analisis konten adalah membuat inferensi. Inferensi diperoleh melalui identifikasi dan penafsiran (Endraswara, 2008:61). Instrumen utama dalam penelitian ini adalah peneliti sendiri. Untuk memudahkan proses penelitian dalam menganalisis dan menginterpretasi

\section{HASIL DAN PEMBAHASAN \\ Hasil}

\section{Sinopsis Novel 212 Cinta Menggerakkan Segalanya Karya Helvy Tiana Rosa dan Benny Arnas.}

Novel 212 Cinta Menggerakkan Segalanya menceritakan pergulatan batin tokoh utama Rahmat Assyraaf Pranaja meenghadapi berbagai konflik dalam kehidupannya. Mulai dari berbagai konflik yang berdampak pada psikologi tokoh utama, misalnya sikap skeptis yang dimiliki Rahmat terhadap agama, Rahmat yang sering bersitenggang dengan ayahnya, seorang tokoh agama di desa yang dianggapnya terlalu keras, dan peristiwa kecelakaan yang dialaminya, sehingga ia kehilangan kedua adiknya. Novel 212 Cinta Menggerakkan Segalanya tersebut ditulis dengan tujuan mengabadikan peristiwa yang terjadi pada aksi 2 
Velly Roista; Emi Agustina; Amril Canrhas

Desember 2016 berupa peristiwa yang luar biasa yang telah menyatukan umat Islam di Indonesia.

\section{Analisis Data Penelitian}

Analisis data dalam penelitian ini yaitu dengan menguraikan struktur novel, sebab akibat peristiwa tersebut, serta wujud nilai-nilai moral yang terdapat dalam novel 212 Cinta Menggerakkan Segala. Nilai-nilai moral yang terdapat dalam novel ditemukan berupa nilai moral baik dan nilai moral buruk. Nilai moral baik terdiri dari keimanan yang meliputi: mencintai Al-Qur'an, konsisten terhadap agama, bersyukur, tawakal, berzikir, penolong, pantang menyerah, kehendak, dan kebahagiaan. Dan moral buruk terdiri atas berbohong, berbuat jahat, perbuatan yang tidak menyenangkan. Kemudian bagian kedua adalah pembahasan hasil penelitian yang menguraikan hasil analisis data.

\section{Struktur Novel}

\section{a. Tema}

Novel 212 Cinta Menggerakkan Segalanya mengangkat tema tentang kisah seorang yang awalnya skeptis terhadap Islam, namun harus terjebak dalam sebuah perjalanan menuju aksi 212 di Monas. Terbukti bahwa dengan cinta mampu menggerakkan segalanya sesuai dengan judul novel tersebut. Apa saja bisa terjadi karena cinta yang telah menggerakkan segalanya, menggerakkan hati para umat umat muslim Indonesia untuk melaksanakan aksi 212 di Monas.

\section{b. Judul}

Judul yang digunakan oleh Helvy Tiana Rosa dan Benny Arnas adalah 212 Cinta Menggerakkan Segalanya. Judul tersebut relevan dengan isi dalam novel karena dengan cinta dapat menggerakkan segalanya. Novel 212 Cinta Menggerakkan Segalanya menguraikan tentang hubungan antarmanusia, dan cinta manusia dengan Tuhannya yang terangkai dalam momen aksi damai 212. Ini adalah bukti kecintaan umat Islam pada Al-Qurean. Karena cinta kepada Allah ternyata bisa menggerakkan segala, yaitu dengan cara damai, dengan kesadaran, bukan ikut-ikutan dan tanpa kekerasan.

\section{c. Amanat}

Amanat dapat diungkapkan secara eksplisit (terang-terangan) dan dapat juga secara implisit (tersirat). Amanat dalam karya sastra ditunjuk sebagai sisi nilai moral dalam sebuah karya sastra. Sisi moral inilah yang disebut sebagai pesan yang akan disampaikan kepada pembaca melalui sebuah karya sastra. Amanat merupakan bagian dari unsur intrinsik dalam karya sastra yang memberikan makna dan jiwa dalam karya sastra tersebut. (Chanafiah, Yayah dan Emi Agustina, 2014:52). Amanat dalam novel 212 Cinta Menggerakkan Segalanya Karya Helvy Tiana Rosa dan Benny Arnas karena siapapun di dunia ini tidak boleh haknya ajaran agama itu saling menjatuhkan, menjelekkan, menghina atau melecehkan agama satu derngan yang lainnya. Jadi, dalam agama itu kita harus saling menghargai dan menghormati keyakinan masing-masing, di mana setiap 
agama itu tujuannya untuk kebaikan dan pada dasarnya agama itu amat penting untuk diperjuangkan.

\section{d. Alur/Plot}

Alur adalah rangkaian yang dibentuk oleh tahapan-tahapan peristiwa sehingga menjalin suatu cerita yang dihadirkan oleh para pelaku dalam suatu cerita. Alur dalam novel 212 Cinta Menggerakkan Segala Karya Helvy TianaRosa adalah alur campuran. Pada awal cerita, novel 212 Cinta Menggerakkan segala Karya Helvy Tiana Rosa dan Benny Arnas menceritakan tentang kerinduan Kiai Zainal dan Ummi Nisa terhadap anak. Kemudian cerita berlanjut menggambarkan situasi keadaan tokoh Rahmat sekarang. Karena tulisan Rahmat menjadi topik utama majalah Republik karena bahasa yang digunakan Rahmat pada tulisan itu terbaca sangat vulgar, tendensius, plus aroma politik yang menyengat. Pada bagian tengah tokoh Rahmat adalah seorang yang skeptis terhadap Islam, apalagi tentang adanya pemberitaan bahwa warga Ciamis akan ikut serta dalam aksi 212, mengetahui hal itu Rahmat berusaha melarang dan menggagalkan dengan berbagai cara agar Abahnya tidak ikut dalam aksi tersebut. Pada bagian akhir cerita menggambarkan kekesalan tokoh Rahmat kepada Kiai Zainal, ia menganggap semua kesalahan Abahnya. Rahmat dan Kiai sering bersitegang, tidak ada yang mau mengalah, dan berbeda pandangan hingga tidak menemukan titik temu agar bersatu. Perjalanan panjang yang menempuh ratusan kilometer itu akhirnya berubah menjadi sebuahperjalanan cinta yang bernilai spesial bagi rahmat dan ayahnya bahwa ia tidakingin menyesal kedua kalinya. Kecintaan kepada Allah dan Al-Qur'an mengubah persepsinya sehingga ia pun begitu bersemangat penuh gairah. Dalam perjalanan Long March itu banyak hal yang dapat ambil hikmahnya, sampai akhirnya ia sadar bahwa agama dan Al-Qur'an amat penting untuk diperjuangkan.

\section{e. Penokohan/watak}

Pnokohan adalah cara pengarang enggambarkan dan mengembangkan karakter tokoh tokoh dalam cerita. Novel 212 Cinta Menggerakkkan Segalanya Karya Helvy Tiana Rosa mempunyai beberapa tokoh yang menjadi pendukung dari jalan cerita dari novel ini sebagai berikut:

1) Ki Zainal dan Ummi Nisa

a) Bersahaja : karakter bersahaja adalah sederhana, tidak berlebih-lebihan.

2) Rahmat

a) Keras kepala: karakter keras kepala yaitu tidak mau menurut nasehat orang. Salah satu karakter yang dimiliki oleh Rahmat adalah keras kepala. Berikut kutipan data yang berkaitan dengan karakter keras.

b) Gengsi: karakter gengsi yaitu kehormatan dan pengaruh, harga diri, martabat (KBBI). Salah satu karakter yang dimiliki Rahmat adalah gengsi. 
Velly Roista; Emi Agustina; Amril Canrhas

\section{f. Latar}

Latar adalah gambaran tentang tempat dan waktu serta segala situasi di tempat terjadinya peristiwa. latar yang ada pada cerita novel 212 Cinta Mengggerakkan Segala Karya Helvy Tiana Rosa dan Benny Arnas sebagai berikut: di rumah, Ciamis, dan Jakarta.

\section{g. Sudut Pandang}

Sudut pandang yang digunakan pada novel 212 Cinta Menggerakkan Segala Karya Helvy Tiana Rosa dan Benny Arnas adalah sudut pandang orang ketiga. Dengan sudut pandang orang ketiga, pusat cerita ada pada Rahmat seorang yang skeptis terhadap Islam, namun harus terjebak dalam sebuah perjalanan menuju aksi 212 di Monas.

\section{h. Gaya Bahasa}

Gaya bahasa yang digunakan novel 212 Cinta Menggerakkan Segala lebih dominan menggunakan bahasa Indonesia dan ditambah sedikit dengan bahasa daerah yaitu bahasa Sunda.

\section{Sebab Akibat dalam Novel 212 Cinta Menggerakkan Segalanya Karya Helvy Tiana Rosa dan Benny Arnas.}

Novel 212 Cinta Menggerakkan Segalanya diciptakan dari sebuah konflikkonflik di masyarakat misalnya dari sudut pandang agama. Seperti contoh judul novel yang diambil dari aksi bela Islam yakni Cinta Menggerakkan Segalanya yang dihasilkan dari sudut pandang agama dan politik di Indonesia yaitu penistaan terhadap agama yang dilakukan oleh Gubernur Basuki Tjahaja Purnama (Ahok) pada tanggal 2 Desember 2016 di daerah DKI Jakarta sebab pidatonya yang menyinggung surat Al-Maidah ayat 51. Dengan adanya aksi tersebut, timbul reaksi atau respon masyarakat melakukan aksi 212 membela agama Islam dengan menunjukkan kekompakkan bersatunya umat muslim di Indonesia maupun di luar Indonesia melakukan berbagai hal, tujuannya agar sebuah ajaran agama tidak disepelehkan untuk kepentingan politik. Mengingat bahwa agama itu pada dasarnya bukan untuk disepelehkan atau dilecehkan, tapi amat penting diperjuangkan. Inti dalam novel Cinta Menggerakkan Segalanya yaitu tentang rasa cinta kepada agama Islam, misalnya diuraikan dalam novel ini bagaimana seorang yang beragama, artinya yang mempercayai satu agama itu merasa agama yang diyakininya itu dilecehkan atau dihina. Dan juga dapat tergambarkan pada tokoh Kiai Zainal yang kondisinya sudah lemah, ia mempunyai semangat yang tinggi untuk melakukan banyak hal karena dorongan moralitas agama itu.

Novel Cinta Menggerakkan Segalanya Karya Helvy Tiana Rosa dan Benny Arnas. Novel ini diangkat dari peristiwa aksi damai membela Islam. Sesuai dengan judulnya, novel ini berbicara tentang kekuatan cinta tuhan yang mampu menggerakkan hati manusia melaksanakan aksi 212. Sekilas novel ini juga menjelaskan tentang cinta anak dan orang tua. Tetapi dalam novel 212 Cinta 
Menggerakkan Segalanya Karya Helvy Tiana Rosa dan Benny Arnas bebicara tentang cinta Tuhan yang dihadirkan lagi di hati orang-orang yang sempat berpaling jauh dari-Nya dengan cara Tuhan yang mampu membolak-balikkan hati manusia, sehingga mampu menggerakkan jutaan hati manusia. Hal ini sejalan dengan tema novel yang menceritakan tentang rasa cinta kepada tuhan,sehingga cerita yang ada dalam novel ini lebih menceritakan tentang kebaikanatau pengarang lebih menggambarkan perbuatan yang sesuai dengan ajaran agama Islam. Maksud dari menggerakkan segalanya ialah tidak ada perbedaan diantara sesama manusia melakukan berbagai hal atau berbuat kebaikan dalam membela agama Islam. Itulah sebabnya orang-orang mampu tergerak menyumbang sebagian hartanya berupa uang, barang, pakaian, makanan, dan tenaganya karena rasa cintanya kepada agama Islam. Sesuatu yang menggerakan itulah yang disebut nilai-nilai, orang melakukan itu karena adanya nilai-nilai yangtertanam pada diri mereka. Wujud nilai moral yang digambarkan dalam noveltersebut merupakan wujud yang menampilkan tokoh-tokoh sesuai dengan wujud asli tokohnya melalui dari jalan cerita, sikap, dan karakter tokoh. Kutipan yang mengandung nilai moral dalam novel 212 Cinta Menggerakkan Segalanya Karya Helvy Tiana Rosa dan Benny Arnas tergambar pada kutipan berikut:

"Ini bukan tentang saya. Bukan hanya tentang saya, kamu, atau diri kita sendiri. Ini tentang rasa cinta pada agama ini”(Rosa dan Arnas, 2018 : 119).

"Kamu ingat, Berapa orang yang tadi berangkat? Dan bagaimana saat ini? Kamu bisa menghitung mereka? Tak kurang dari 10.000 orang! Kami adalah mata rantai- mata rantai yang berkaitan itu, yang membentuk kekuatan tanpa kami rencanakan. Kamu masih mau bertanya bagaimana ini terjadi? ini karena cinta. cinta apa? cinta pada agama ini!" (Rossa dan Arnas, 2018: 121).

Kutipan tersebut menguraikan tentang rasa cinta kepada agama Islam yang membuat orang tergerak membela agama Islam. Contohnya pada wujud keimanan Kiai Zainal yang memiliki sikap tangguh dengan agama yang dianutnya, hal itu ditegaskan dalam kutipan di atas, siapapun yang melecehkan agamanya akan dilawan walaupun orang itu adalah sahabatnya. Kutipan kedua, dan ketiga juga merupakan wujud penerapan kecintaan terhadap agama Islam karena agama Islam dinistakan, sehingga muncul kemantapan hati Kiai Zainal dan umat muslim di Indonesia melakukan aksi membela agama Islam. Dari kutipan di atas mengapa hal itu bisa terjadi, hal itu disebabkan karena terdapat nilai-nilai moral di dalamnya. Hal itu ditegaskan dari kutipan di atas, itu sebabnya umat muslim di Indonesia tergerak dari provinsi aceh hingga papua beramai-ramai ikut melaksanakan aksi tersebut karena membela agama Islam. Mengingat bahwa agama itu pada dasarnya bukan untuk disepelehkan atau dilecehkan, tapi amat penting diperjuangkan. Kutipan yang terdapat moral baik dalam novel 212 Cinta Menggerakkan Segalanya Karya Helvy Tiana Rosa dan Benny Arnas tergambar pada kutipan berikut: 
"Tukang ketoprak sedang menempelkan sebuah kertas dengan tinta spidol bertuliskan "dagangan saya hari ini sudah dibayar lunas oleh Allah untuk kalian" di kaca depan gerobaknya"(Rosa dan Arnas, 2018:178).

"Minuman dan makanan nak, seorang wanita paruh baya bertopi lebar menyodorkan minuman kemasan dan kue-kue"(Rosa dan Arnas, 2018:221).

"Saya hanya mengikuti kata hati, Mas. Keimanan dan kecintaanlah yang menggerakkan semua orang untuk melakukan ini”'(Rosa dan Arnas, 2018:222).

Kutipan tersebut menggambarkan rasa cinta kepada agama yang membuat orang bergerak hatinya melakukan kebaikan, itulah yang ditegaskan dalam kutipan di atas, seperti tukang ketoprak dan sosok ibu-ibu pedagang makanan yang tidak hentinya menawarkan dagangannya secara cuma-cuma kepada orang lain demi kecintaannya kepada agama Islam yang membuat tergerak hatinya ikut aksi damai tersebut. Dari kutipan di atas mengapa hal itu bisa terjadi, hal ini disebabkan karena terdapat nilai-nilai moral dalam diri mereka. Hal itu ditegaskan dari kutipan di atas, bagaimana orang-orang yang hanya berjualan di pinggir jalan yang hanya mengandalkan dagangannya untuk memenuhi kebutuhan hidupnya, mereka rela membagikan dagangannya kepada orang lain secara cuma-cuma karena kecintaannya kepada Tuhan-Nya.

Kutipan moral buruk dalam novel 212 Cinta Menggerakkan Segalanya Helvy Tiana Rosa Dan Benny Arnas dapat tergambarkan sebagai berikut:

"Kan bisa saja dalam hati kecil bapak ibu ngga pilih saya karena dibohongi (pakai surat Al-Maidah ayat 51 macam-macam itu. Itu hak bapak/ibu. Kalau bapak/ibu merasa ngga pilih karena takut masuk neraka, dibodohin, begitu oh ngga apa-apa, karena ini panggilan pribadi ibu/bapak) (Rossa dan Arnas, 2018:12).

"Bus yang dihadang oleh sepasukan polisi membuat beberapa penumpang panik dan rahmat berusaha memanfaatkannya dengan menyarankan sopir untuk putar balik".(Rossa dan Arnas, 2018: 177). "Saya nggak peduli Abah mau ngomong apa! Saya muak dengan semua ini! Rahmat menghentikan seretannya. "Saya paksa Abah pulang sekarang juga!'(Rosa dan Arnas, 2018 :212).

"Kita semua ini sedang diperalat oleh -Nya. Oleh Tuhan. Tuhan itu tidak butuh pembelaan "(Rosa dan Arnas, $2018: 221$ ).

Berdasarkan kutipan di atas, menguraikan nilai moral buruk yang disebabkan karena ucapan ahok yang menyinggung surat Al-Maidah ayat 51 sehingga, membuat orang merasa tidak nyaman, terhina atau terlecehkan karena 
ucapannya. Terdapat kutipan lainnya yakni pasukan polisi yang menghalangi umat muslim untuk melakukan aksi tetapi dengan cara tersebut orang-orang masih tetap bergerak karena membela agama. Dan juga terdapat kutipan lainnya dari tokoh Rahmat yang tidak memiliki rasa cinta terhadap agama yang dianutnya. Artinya, sikap tokoh Rahmat yang melawan gerakkan tersebut atau menyepelehkan agama. Dan juga di kutipan lainnya bagaimana tokoh rahmat yang menghalangi ayahnya dengan memaksanya untuk tidak ikut aksi. Hal itu tersebut merupakan perbuatan moral yang tidak terpuji dari tokoh Rahmat.

\section{Bentuk-Bentuk Nilai Moral baik dan buruk dalam Novel 212 Cinta Menggerakkan Segalanya Helvy Tiana Rosa dan Benny Arnas.}

Berdasarkan analisis data tersebut nilai-nilai moral dibedakan atas nilai moral yang baik dan nilai moral yang buruk. Berdasarkan hasil analisis data nilai moral baik dalam wujud keimanan yang ditemukan dalam novel 212 Cinta Menggerakkan Segalanya Karya Helvy Tiana Rosa dan Benny Arnas meliputi (1) mencintai Al-Qur'an, (2) tawakal, (3) konstisten terhadap agama, (4) bersyukur, (5) berdzikir. Nilai moral buruk yang terdapat dalam novel 212 Cinta Menggerakkan Segalanya Karya Helvy Tiana Rosa dan Benny Arnas terdiri dari bohong, jahat, perbuatan yang tidak menyenangkan, seperti sikap menghalangi orang bebuat kebaikan dan tidak peduli kepada orang lain.

\section{B. Pembahasan}

Secara umum moral menyarankan pada pengertian ajaran tentang baik buruk yang diterima umum mengenai perbuatan, sikap, kewajiban, akhlak, budi pekerti. Misalnya pada novel 212 Cinta Menggerakkan Segalanya Karya Helvy Tiana Rosa dan Benny Arnas yakni dari peristiwa tersebut memiliki nilai-niilai dari sudut pandang agama karena siapa pun di dunia ini tidak boleh haknya ajaran agama itu saling menjatuhkan dan saling menjelekkan antara satu dengan yang lain atau keyakinan satu dengan keyakinan yang lainnya. Jadi ada nilai moralnya misalnya, tidak saling menjatuhkan dan tidak saling menjelekkan. Hal itu sudah dilakukan oleh seseorang, sehingga di situ ada gerakan secara moral. Novel 212 Cinta Menggerakkan Segalanya Karya Helvy Tiana Rosa dan Benny Arnas dimaksudkan mengabadikan peristiwa aksi 212 dan novel ini juga membawa pesan damai dari umat Islam di Indonesia.

Novel 212 Cinta Menggerakan Segalanya Karya Helvy Tiana Rosa dan Benny Arnas berbicara tentang rasa cinta kepada agama Islam yang membuat orang bergerak melakukan segalanya, mungkin semua bab itu berbicara tentang cinta dalam pengertian tertentu. Sekilas novel tersebut menjelaskan hubungan cinta antara anak kepada orang tua dan juga menjelaskan hubungan cinta manusia kepada Tuhan-Nya. Tetapi di dalam novel 212 Cinta Menggerakan Segalanya Karya Helvy Tiana Rosa dan Benny Arnas berbicara tentang kekuatan cinta Tuhan. Penyebab peristiwa itu terjadi karena ucapan Ahok yang menyinggung surat $\mathrm{Al}$-Maidah ayat 51 yang membuat mereka merasa dihina atau dilecehkan. Berdasarkan itulah muncul reaksi atau respon masyarakat yang membuat orang bergerak hati nurani masing-masing manusia melakukan aksi 
212 dengan menunjukkan kekompakkan bersatunya umat muslim di Indonesia berkumpul di monas dari provinsi aceh hingga papua melakukan berbagai hal dalam membela agama Islam. Semua perilaku manusia itu didasari oleh nilai. Hal tersebut muncul karena adanya nilai moral yang ada pada diri mereka. Maksud dari menggerakkan segalanya ialah tidak ada perbedaan diantara sesama manusia untuk melakukan segalanya atau berbuat kebaikan dalam membela agama Islam, contohnya orang-orang mampu tergerak hatinya untuk menyumbang sebagian hartanya berupa uang, barang, makanan, dan tenaganya karena rasa cintanya kepada agama Islam yang terangkai dalam aksi 212. Hal tersebut timbul karena mereka memiliki nilai semangat juang, orang bergerak karena membela agama. Seperti yang digambarkan oleh tokoh Kiai Zainal dan umat mulim di Indonesia melakukan berbagai hal karena kecintaannya kepada Tuhan-Nya.Mengingat bahwa agama itu pada dasarnya bukan untuk disepelehkan atau dilecehkan, tapi untuk diperjuangkan. Salah satu yang harus dimiliki manusia dalam kehidupan seperti kejujuran, tanggung jawab, dan keadilan.

Sesuai dengan judulnya apa saja bisa terjadi. Itu sebabnya karena rasa cinta kepada agama yang mampu menggerakkan segalanya, menggerakkan hati para umat muslim di Indonesia melaksanakan aksi 212 di Monas. Mengapa orang melakukan itu, hal itu bisa terjadi karena nilai moral. Bukan karena mereka memiliki banyak materi, tapi mereka orang biasa. Hal itu bisa terjadi karena mereka memiliki nilai-nilai yang ada pada diri mereka. Contohnya mereka yang hanya tinggal di rumah yang terbuat dari dinding kayu dan dilengkapi papan lintang tanah, tapi mereka bisa melakukan banyak hal yang membuat orang bergerak. Dan juga terdapat contoh lainnya misalnya, bagaimana orang yang berjualan dipinggir jalan hanya mengandalkan barang dagangannya, tetapi ia rela membagikannya secara gratis kepada orang lain. Hal itu muncul karena mereka memiliki nilai-nilai mereka sanggup tidak makan karena kecintaannya kepada Tuhan-Nya.

Nilai moral dalam novel 212 Cinta Menggerakkan Segalanya Karya Helvy Tiana Rosa dan Benny Arnas merupakan hubungan manusia dengan tuhannya dan manusia dengan manusia lain dalam kehidupan bermasyarakat, seringkali terjadi gesekan kepentingan. Persoalan hidup sesama manusia dengan lingkungannya dapat berupa persoalan yang positif maupun persoalan yang negatif seperti yang digambarkan oleh tokoh Rahmat, Kiai Zainal, dan umat muslim di Indonesia mengingat bahwa manusia pada dasarnya adalah makhluk sosial yang saling membutuhkan satu sama lain termasuk hubungan dengan alam sekitar sebagai kelengkapan dalam kehidupannya terkadang menimbulkan berbagai macam permasalahan. Berdasarkan hasil penelitian, wujud nilai moral yang digambarkan dalam novel 212 Cinta Menggerakan Segalanya Karya Helvy Tiana Rosa dan Benny Arnas di temukan wujud nilai moral baik dan buruk. Hasil temuan tersebut jika dikaitkan dengan pendapat Asmaran (2002: 27-28) tentang wujud nilai moral baik meliputi keimanan, penolong, kehendak, pantang menyerah dan kebahagiaan dan wujud moral buruk meliputi bohong, jahat, dan perbuatan yang tidak menyenangkan (melanggar norma). Nilai moral yang terdapat dalam novel 212 Cinta Menggerakan Segalanya Karya Helvy Tiana Rosa 
dan Benny Arnas dapat dikategorikan sebagai novel yang memiliki pembelajaran moral yang baik bagi pembaca. Pengarang banyak menampilkan pembelajaran moral yang dapat dicontoh oleh pembaca.

Berdasarkan hasil penelitian, nilai moral baik yang ditemukan dalam novel 212 Cinta Menggerakkan Segalanya Karya Helvy Tiana Rosa dan Benny Arnas terdiri dari (1) keimanan yang meliputi: mencintai Al-Qur'an, konstisten terhadap agama, bersyukur, tawakal atau berserah diri, (2) penolong, (3) pantang menyerah, (4) kehendak, dan (5) kebahagiaan. Hasil temuan tersebut sejalan jika dikaitkan dengan pendapat Asmaran (2002: 27-28) tentang wujud nilai moral baik meliputi: keimanan, penolong, pantang menyerah, kehendak, dan kebahagiaan.

\section{PENUTUP}

\section{Kesimpulan}

Berdasarkan hasil analisis sebelumnya, dapat disimpulkan sebagai berikut: Novel 212 Cinta Menggerakkan Segalanya mengekspresikan rasa cinta kepada agama Islam yang terwujud dalam aksi damai pada tanggal 2 Desember 2016 yaitu peristiwa luar biasa karena pada saat itu tujuh juta orang memenuhi kawasan Monumen Nasional (Monas). Hal ini disebabkan karena adanya penistaan terhadap agama. itu sebabnya mereka tergerak menyumbang sebagian hartanya berupa uang, barang, makanan, dan tenaganya karena rasa cinta kepada agama Islam, dan juga penulis mengambil kesimpulan bahwa dalam Novel 212 Cinta Menggerakkan Segalanya terdapat wujud nilai moral baik dan moral buruk. Nilai moral baik yang dominan dalam novel 212 Cinta Menggerakkan Segalanya yakni wujud keimanan, karena keimanan itulah yang membuat mereka bergerak, Moral buruk yang dimiliki tokoh Rahmat dan pasukan polisi terdiri atas berbohong, berbuat jahat, perbuatan yang tidak menyenangkan seperti, menghalangi orang bebuat kebaikan, dan sikap tidak peduli kepada orang lain. Berdasarkan hasil penelitian dapat dikategorikan novel dengan nilai moral baik, karena menggambarkan pembelajaran moral yang baik bagi pembacanya.

Dengan demikian, dapat dikatakan bahwa novel 212 Cinta Menggerakkan Segalanya mengekspresikan tentang rasa cinta kepada agama yang mampu menggerakkan segalanya. Novel ini dapat dikategorikan novel dengan nilai moral baik, karena banyak menggambarkan pembelajaran moral yang baik bagi pembacanya.

\section{Saran}

Mengingat karya sastra merupakan gambaran kehidupan, penelitian pada karya sastra perlu ditingkatkan dan dapat dilanjutkan pada analisis yang lain. Dan juga penelitian ini dapat memberikan motivasi kepada pembaca untuk terus meningkatkan dan menjaga nilai-nilai moral, serta mengimplementasikannya dalam kehidupan bermasyarakat. 
Velly Roista; Emi Agustina; Amril Canrhas

\section{DAFTAR RUJUKAN}

Asmaran, A.S.2002. Pengantar Studi Ahklak (Moral). Jakarta :Raja Grafindo Persada.

Chanafiah, Yayah dan Emi Agustina.2014. Buku Ajar Apresiasi Prosa Fiksi. Bengkulu: Universitas Bengkulu.

Endraswara, Suwardi.2008. Metodologi Penelitian Sastra. Yogyakarta: MeedPress.

Esten, Mursal. 1978.Kesustraan Pengantar Teori dan Sejarah.Bandung: CV Angkasa.

Hakam, Abdul Karna dan Nurdin, Encep Syarif.2016. Metode Internalisasi NilaiNilai untuk Memodifikasi Perilaku Berkarakter.Bandung:Maulana Medika Grafika.

Kosasih, E.2012. Dasar-Dasar Keterampilan Besastra.Bandung: Yrama Widya. Meleong, Lexy J.2014.Metodologi Penelitian Kualitatif. Bandung: Remaja Rosdakarya.

Muchson dan Samsuri. 2013.Dasar-Dasar Pendidikan Moral (Basis Pengembangan Pendidikan Karakter).Yogyakarta: Ombak.

Nurgiyantaro, Burhan.2013.Teori Pengkajian Fiksi.Yogyakarta: Gajah Mada University Press.

Ratna, Nyoman Kutha.2012.Teori Metode dan Teknik Penelitian Satra. Yogyakarta: Pustaka Pelajar.

Rosa, Helvy Tiana dan Benny Arnas. 2018. Cinta Menggerakkan Segalanya. Jakarta: Republika.

Salfia, Nining. 2015. Nilai Moral Dalam Novel 5 CM Karya Donny Dhirgantoro. Jurnal Humanika, No.15, Vol 3, Desember 2015/ISSN 1979- 8296.

Sari, Nurmala. 2019. Novel 212 Cinta Menggerakkan Segalanya Karya Helvy Tiana Rosa dan Benny Arnas Kajian Struktur. Medan: FKIP UMS.

Semi, M Atar.1988. Anatomi Sastra. Bandung: Cv Angkasa. 